\title{
Transportable data from non-target arthropod field studies for the environmental risk assessment of genetically modified maize expressing an insecticidal double-stranded RNA
}

\author{
Aqeel Ahmad • Ignacio Negri • Wladecir Oliveira • Christopher Brown • \\ Peter Asiimwe - Bernard Sammons • Michael Horak • Changjian Jiang • \\ David Carson
}

Received: 7 May 2015/ Accepted: 23 September 2015/Published online: 3 October 2015

(C) The Author(s) 2015. This article is published with open access at Springerlink.com

\begin{abstract}
As part of an environmental risk assessment, the potential impact of genetically modified (GM) maize MON 87411 on non-target arthropods (NTAs) was evaluated in the field. MON 87411 confers resistance to corn rootworm (CRW; Diabrotica spp.) by expressing an insecticidal double-stranded RNA (dsRNA) transcript and the Cry3Bb1 protein and tolerance to the herbicide glyphosate by producing the CP4 EPSPS protein. Field trials were conducted at 14 sites providing high geographic and environmental diversity within maize production areas from three geographic regions including the U.S., Argentina, and Brazil. MON 87411, the conventional control, and four commercial conventional reference hybrids were evaluated for NTA abundance and damage. Twenty
\end{abstract}

Electronic supplementary material The online version of this article (doi:10.1007/s11248-015-9907-3) contains supplementary material, which is available to authorized users.

A. Ahmad $(\bowtie) \cdot$ C. Brown · P. Asiimwe .

B. Sammons - M. Horak · C. Jiang · D. Carson

Monsanto Company, 800 N. Lindbergh Boulevard,

St. Louis, MO 63141, USA

e-mail: aqeel.ahmad@monsanto.com

I. Negri

Monsanto Company, Fontezuela Research Station Route 8, km214, CP2700 Pergamino, Buenos Aires, Argentina

\section{W. Oliveira}

Monsanto Company, Dionisio Bortolotti Avenue, km 0.5, Caixa Postal 9, Santa Cruz das Palmeiras, São Paulo, Brazil arthropod taxa met minimum abundance criteria for valid statistical analysis. Nine of these taxa occurred in at least two of the three regions and in at least four sites across regions. These nine taxa included: aphid, predatory earwig, lacewing, ladybird beetle, leafhopper, minute pirate bug, parasitic wasp, sap beetle, and spider. In addition to wide regional distribution, these taxa encompass the ecological functions of herbivores, predators and parasitoids in maize agro-ecosystems. Thus, the nine arthropods may serve as representative taxa of maize agro-ecosystems, and thereby support that analysis of relevant data generated in one region can be transportable for the risk assessment of the same or similar GM crop products in another region. Across the 20 taxa analyzed, no statistically significant differences in abundance were detected between MON 87411 and the conventional control for 123 of the 128 individual-site comparisons (96.1\%). For the nine widely distributed taxa, no statistically significant differences in abundance were detected between MON 87411 and the conventional control. Furthermore, no statistically significant differences were detected between MON 87411 and the conventional control for 53 out of 56 individual-site comparisons $(94.6 \%)$ of NTA pest damage to the crop. In each case where a significant difference was observed in arthropod abundance or damage, the mean value for MON 87411 was within the reference range and/or the difference was not consistently observed across collection methods and/or sites. Thus, the differences were not representative of an adverse effect unfamiliar 
to maize and/or were not indicative of a consistent plant response associated with the GM traits. Results from this study support a conclusion of no adverse environmental impact of MON 87411 on NTAs compared to conventional maize and demonstrate the utility of relevant transportable data across regions for the ERA of GM crops.

Keywords Genetically modified crop · Insecticidal double-stranded RNA · Bacillus thuringiensis · Nontarget arthropods - Environmental risk assessment . Transportability

\section{Introduction}

Prior to commercialization of a genetically modified (GM) crop, a science-based environmental risk assessment (ERA) is conducted to assess for potential harmful effects on human and animal health, and the environment. This process has been described in detail by a number of regulatory agencies worldwide [e.g., USDA-APHIS (CFR 2008), the U.S. Environmental Protection Agency (US EPA 1998), the Canadian Food Inspection Agency (CFIA 2012), and the European Union (EFSA 2004)]. For insect-protected GM crops, a step-wise, tiered testing approach using surrogate species within the framework of problem formulation is recognized as the most appropriate and rigorous approach to assess for potential effects on non-target organisms in many regulatory frameworks (Rose 2006; US EPA 2007; Romeis et al. 2008; Wolt et al. 2010). In this tiered approach, risk (a function of hazard and exposure) is evaluated within different levels or "tiers" that progress from worst-case exposure scenarios to real-world field scenarios if the earlier tiered tests fail to indicate adequate certainty of acceptable risk (Romeis et al. 2008; Duan et al. 2010).

In the ERA of GM crops, plant characterization studies are also conducted under diverse geographic and environmental conditions to assess potentially adverse effects of the GM crops on its receiving environment, relative to an appropriate conventional control that is genetically similar but lacks the introduced trait (Raybould 2007; Horak et al. 2007; Nickson 2008; Raybould 2010; Wolt et al. 2010; Horak et al. 2015a, b). These studies are used by risk assessors and regulators to determine whether cultivation and/or import of a GM crop is acceptable in a particular region.

Non-target arthropod (NTA) field evaluations are conducted when needed as an important part of plant characterization and are utilized in an overall ERA of the GM crop. The purpose of these evaluations is to confirm the results of the early tier testing and address any uncertainties in the risk assessment by collecting meaningful data on NTAs that are closely associated with the plant (Romeis et al. 2006, 2008). NTAs are selected based on criteria that they are sufficiently abundant in the crop of interest, exhibit low mobility and possess a clear path of exposure (e.g., non-target herbivores) (Prasifka et al. 2008; Romeis et al. 2009; Rauschen et al. 2010a, b; Romeis et al. 2013). Results from these evaluations, which may be considered higher tier, "real-world" assessments, aid in the ERA to reduce uncertainty of unintended effects through collection of in planta data. While NTA field data for plant characterization may be confirmatory of the tiered approach, a key distinction between the environmental interactions assessment and a higher-tier NTA field study is that the latter is conducted only if results from lower-tier laboratory NTA testing fail to indicate acceptable environmental risk for the GM crop product.

It is important that risk assessors and regulators have access to and utilize environmental assessment data on the crop and trait that are generated in other relevant geographic regions (Roberts et al. 2014; Garcia-Alonso et al. 2014; Horak et al. 2015a, b). The results from well-designed studies conducted in the field, greenhouse, or laboratory and used for ecological risk assessments are relevant and transportable to other geographies for the ERA of the same GM crop, or related traits or GM crop/trait combinations where the ecological assessment endpoints are similar. Leveraging existing, relevant data for the ERA of GM crops across regions will conserve resources, eliminate redundancy, and support conclusions with high certainty for assessing potential environmental risk from the commercial release of a GM crop.

Monsanto Company has developed GM maize, MON 87411 that confers resistance to corn rootworm (CRW; Diabrotica spp.) and tolerance to the herbicide glyphosate. MON 87411 contains a suppression cassette that expresses an inverted repeat sequence designed to match a partial sequence of the Snf7 gene from western corn rootworm (WCR; Diabrotica virgifera virgifera). The expression of the suppression 
cassette results in the formation of a double stranded RNA (dsRNA) transcript containing a $240 \mathrm{bp}$ fragment of the WCR Snf7 gene (DvSnf7) (Bolognesi et al. 2012). Upon consumption, the plant-produced dsRNA in MON 87411 is recognized by the CRW's RNA interference (RNAi) machinery resulting in downregulation of the targeted DvSnf7 gene leading to CRW mortality (Bolognesi et al. 2012). MON 87411 also contains a Cry3Bb1 gene that produces a modified Bacillus thuringiensis (Bt) (subsp. kumamotoensis) $\mathrm{Cry} 3 \mathrm{Bb} 1$ protein to protect against CRW larval feeding. In lab studies, the snf7 ortholog has been shown to have a very specific and narrow spectrum of activity limited to the Galerucinae subfamily of Chrysomelidae (Bachman et al. 2013). In addition, MON 87411 contains the cp4 epsps gene from Agrobacterium sp. strain CP4 that encodes for the 5-enolpyruvylshikimate-3-phosphate synthase (EPSPS) protein, which confers tolerance to glyphosate, the active ingredient in Roundup ${ }^{\circledR}$ agricultural herbicides. MON 87411 builds upon the current $B t$ protein-based mode-of-action (MOA) for CRW control by the addition of a new RNAi-based MOA that offers enhanced control of target insect pests and prolonged durability of existing $B t$ technologies designed to control CRW.

Several studies have demonstrated the absence of adverse effects of crops expressing $B t$ proteins on nontarget arthropods in the lab or field (Li and Romeis 2009, 2010, 2011; Ahmad et al. 2005, 2006; Bhatti et al. 2005a, b; Naranjo et al. 2005; Naranjo 2009; Marvier et al. 2007; Duan et al. 2008a, b; Rauschen et al. 2010a, b; Rosca and Cagan 2012a, b; Comas et al. 2014), however no published study has evaluated the effect of an RNA-based trait stacked with $B t$ proteins on abundance of NTAs in the field. This study evaluated the effect of MON 87411 on the abundance of NTAs relative to its conventional control in maize fields in three separate geographic regions, the U.S., Argentina, and Brazil. In addition, plant damage from major nontarget pests was evaluated to determine whether MON 87411 had any increased or decreased susceptibility to these pests, providing more information on potential harmful effects for the ERA. Since the studies are conducted in diverse geographic regions representing a broad range of environmental conditions and agricultural ecosystems, and given the similarity of the endpoints being assessed, these results could be "transportable" to other countries. This paper also provides data supporting the concept of data transportability, where results on NTA data with proper justification can be leveraged across regions to support ERA.

\section{Materials and methods}

Study sites and materials

Data were collected from field trials conducted at four sites in the U.S. during the 2012 season, four sites in Argentina during the 2012-2013 season, and six sites in Brazil during the 2013-2014 season. These field sites provided a range of environmental and agronomic conditions representative of commercial maize production in all three regions. At each site, MON 87411, the conventional control, and four commercial conventional reference hybrids were planted in a randomized complete block design with four replications. The control material has a genetic background similar to MON 87411 with the exception of the insect-protected and glyphosate tolerant traits; it does not contain the inserted genes present in MON 87411. The reference hybrids were commercially available and varied by site and study, thereby providing a range of values common to commercial maize for the assessed characteristics. Details on all study sites are given in Table 1. At each site, the entire study area was treated with the same agronomic inputs (e.g. fertilizer, irrigation, pesticides) to ensure uniform agronomic conditions.

NTA abundance and damage assessments

\section{Sticky traps}

Arthropods were collected using yellow sticky traps (Pherocon AM, no-bait sticky traps; Great Lakes Integrated Pest Management, Vestaburg, MI) at five times during the growing season: late vegetative-VT, R1, R2, R3, and R4 growth stage (U.S. and Argentina) and V13-V15, VT-R1, R1-R2, R2-R3 and R3-R4 growth stage (Brazil). In each plot, sticky traps (two per plot in U.S. and Argentina; four per plot in Brazil) were deployed for approximately 7 days at the approximate midpoint between the ground level and the top of the plant canopy. Arthropods collected from sticky traps were identified and enumerated by skilled personnel/entomologists. 
Table 1 Description of Field Sites Used to Evaluate MON 87411

\begin{tabular}{|c|c|c|c|c|c|c|c|}
\hline Site $^{1}$ & Planting date ${ }^{2}$ & Harvest date $^{2}$ & $\begin{array}{l}\text { Planting } \\
\text { rate (seeds/m) }\end{array}$ & Plot Size $(\mathrm{m} \times \mathrm{m})$ & Soil type & $\% \mathrm{OM}^{3}$ & Previous crop \\
\hline \multicolumn{8}{|l|}{ USA } \\
\hline IABG & 05/09/12 & $10 / 05 / 12$ & 7.2 & $6.1 \times 12.2$ & Loam & 4.0 & Soybean \\
\hline NCBD & 05/11/12 & $09 / 20 / 12$ & 6.6 & $6.1 \times 15.5$ & Sandy Loam & 2.6 & Cotton \\
\hline NEYO & 05/08/12 & $10 / 09 / 12$ & 7.2 & $6.1 \times 12.2$ & Silt Loam & 3.0 & Soybean \\
\hline PAHM & 05/19/12 & $10 / 19 / 12$ & 8.2 & $6.1 \times 12.2$ & Loam & 1.6 & Vegetables ${ }^{4}$ \\
\hline \multicolumn{8}{|l|}{ Argentina } \\
\hline BAFE & $12 / 11 / 12$ & $05 / 10 / 13$ & 6.0 & $9.8 \times 10$ & Loam & 3 & Corn \\
\hline BAGH & $12 / 12 / 12$ & $05 / 21 / 13$ & 7.0 & $9.8 \times 10$ & Silt Loam & 2.6 & Soybeans \\
\hline ERMY & 01/07/13 & $06 / 18 / 13$ & 7.0 & $7.28 \times 10$ & Silt Loam & 3.5 & Soybeans \\
\hline TMBU & $01 / 20 / 13$ & $06 / 03 / 13$ & 6.0 & $7.28 \times 10$ & Loam & 3.8 & Wheat \\
\hline \multicolumn{8}{|l|}{ Brazil } \\
\hline BALM & $11 / 24 / 13$ & $04 / 07 / 14$ & 7.0 & $6.4 \times 5.0$ & Sand & 1.7 & Fallow \\
\hline $\mathrm{MGCH}$ & $11 / 14 / 13$ & $04 / 04 / 14$ & 7.0 & $6.4 \times 5.0$ & Loam & 2.5 & Soybeans \\
\hline MTSO & $11 / 22 / 13$ & $03 / 18 / 14$ & 7.0 & $6.4 \times 5.0$ & Loam & 3.0 & Fallow \\
\hline PRRO & $11 / 14 / 13$ & $04 / 23 / 14$ & 7.0 & $6.4 \times 5.0$ & Loam & 2.2 & Oat \\
\hline RSNM & $11 / 24 / 13$ & $04 / 17 / 14$ & 7.0 & $6.4 \times 5.0$ & Loam & 2.7 & Oat \\
\hline SPSD & $11 / 13 / 13$ & $04 / 09 / 14$ & 7.0 & $6.4 \times 5.0$ & Loan & 2.8 & Millet \\
\hline
\end{tabular}

1 Site code: $\mathrm{IABG}=$ Greene County, IA; NCBD = Perquimans County, NC; NEYO = York County, NE; PAHM = Berks County, PA. BAFE = Ferré, Buenos Aires; BAGH = Gahan, Buenos Aires; ERMY = Montoya, Entre Ríos; TMBU = Burruyacú, Tucumán; BALM = Luis Eduardo Magalhães, BA; MGCH = Cachoeira Dourada, MG; MTSO = Sorriso, MT; PRRO = Rolândia, PR; RSNM = Não-Me-Toque, RS; SPSD = Santa Cruz das Palmeiras, SP

2 Planting and Harvest Date $=\mathrm{mm} / \mathrm{dd} / \mathrm{yy}$

$3 \% \mathrm{OM}=$ Percent Organic Matter

4 Vegetables = peppers, tomatoes, potatoes, cabbage, maize

\section{Visual counts}

Visual counts were conducted at 5-6 times during the growing season: late vegetative, VT-R1, R1, R2, R3, and R4-R5 (U.S. and Argentina) and V13-V15, VTR1, R1-R2, R2-R3 and R3-R4 (Brazil) from 5 to 10 non-systematically selected plants per plot. Visual counts for arthropod abundance were made by examining the stalk, leaf blade, leaf collar, ear tip, silk, and tassel of each plant.

\section{Arthropod damage}

In the U.S., damage from two non-target arthropod pests: Helicoverpa zea and Ostrinia nubilalis, was evaluated. Ear damage from H. zea was assessed at R5 by examining ten plants from two rows. Where damage was present, assessment was made using a plastic film grid $\left(0.5 \mathrm{~cm}^{2}\right.$ per grid $)$ placed over the damaged area and counting the number of grid cells containing $50 \%$ or greater damage. O. nubilalis damage was evaluated at R6 growth stage by splitting the stalk of 10 plants from two rows and recording the number and total length $(\mathrm{cm})$ of all feeding galleries.

In Argentina and Brazil, damage from three nontarget arthropod pests; H. zea, Diatraea saccharalis, and Spodoptera frugiperda, was evaluated. Ear damage from $H$. zea (Argentina) and Lepidopteran Insects, H. zea and S. frugiperda (Brazil) was assessed at R5R6 using the methods described above for the U.S. study. D. saccharalis damage was evaluated at R6 growth stage by splitting the stalk of 10 plants from two rows and recording the number and total length (cm) of all feeding galleries. Leaf damage from $S$. frugiperda was evaluated up to 5 times, when larvae were actively causing damage, using a 0-9 Davis scale (Davis et al. 1992). 
Data analysis

\section{Arthropod abundance data}

The primary focus of the study was on the effects of MON 87411 and the conventional control on the mean count of each arthropod during the entire season in each region. In order to conduct a valid analysis of the material effect on arthropod counts, a two-part inclusion criteria was used. To meet the inclusion criteria for analysis, a mean count across all collection times per plot $\geq 1$ was required for each site to be included in the analysis. Secondly, an average of at least one capture per replicate was required for each collection time to meet the standard for inclusion criteria. Data combinations with counts below these criteria were excluded from significance testing but summarized in Supplementary material. Two separate analyses were performed for the arthropod abundance data:

(a) An across-collection analysis was performed separately for each combination of collection method, arthropod taxa, region, and site using the following model:

$$
\begin{aligned}
y_{i j k}= & \mu+B_{i}+M_{j}+(B M)_{i j}+C_{k} \\
& +(B C)_{i k}+(M C)_{j k}+e_{i j k}
\end{aligned}
$$

where $y_{i j k}=$ square-root of the observed count; $\mu=$ overall mean; $B_{i}=$ random replicate effect; $M_{j}=$ fixed material effect; $(B M)_{i j}=$ random interaction of replicate and material; $C_{k}=$ random collection effect; $(B C)_{i k}=$ random interaction of replicate and collection; $(M C)_{\mathrm{jk}}=$ random interaction effect of material and collection; and $e_{i j k}=$ residual effect. PROC MIXED using SAS ${ }^{\circledR}$ (SAS 2008, 2012) was used to fit model (1) to the data. Heterogeneous variance was assumed to accommodate the observed heterogeneity among collections. A square-root variance stabilizing transformation was used to account for the count nature of the data. Pairwise comparisons between MON 87411 and conventional control materials were defined within the ANOVA and tested using $t$ tests.

(b) An across-region-site-collection analysis was performed for insects captured in at least two regions using the following model:

$$
\begin{aligned}
y_{i j k l m}= & \mu+R_{i}+S_{j(i)}+B_{k(i j)}+M_{l} \\
& +(R M)_{i l}+(B M)_{k l(i j)}+(S M)_{j l(i)}+C_{m(i j)} \\
& +(B C)_{k m(i j)}+(M C)_{l m(i j)}+e_{i j k l m}
\end{aligned}
$$

where $y_{i j k l m}=$ square-root of the observed count; $\mu=$ overall mean; $R_{i}=$ fixed region effect; $S_{j(i)}=$ random site effect within region; $B_{k(i j)}=$ random replicate (block) effect within each site; $M_{l}=$ fixed material effect; $(R M)_{i l}=$ fixed interaction of region and material; $(B M)_{k l(i j)}=$ random interaction of replicate and material; $C_{m(i j)}=$ random collection effect within each site; $(S M)_{j l(i)}=$ random interaction of material and site within region; $(B C)_{k m(i j)}=$ random interaction of replicate and collection; $(M C)_{\operatorname{lm}(i j)}=$ random interaction of material and collection time; and $e_{i j k l m}=$ residual effect. This model is essentially the same as model (1) above for each site except for the addition of the fixed effects of region and its interaction with the material and random site effects within each region. PROC MIXED using SAS $^{\circledR}$ (SAS 2008, 2012) was used to fit model (2) to nine insects with data from at least two regions reaching the site-inclusion criteria. Pairwise comparisons between MON 87411 and conventional control materials were defined within the ANOVA and tested using $t$ tests.

\section{Arthropod damage data}

A combined-site ANOVA was conducted according to the following model for a randomized complete block design:

$y_{i j k}=\mu+S_{i}+M_{j}+(S M)_{i j}+B(S)_{k(i)}+e_{i j k}$

in which $y_{i j k}$ is the observed arthropod damage, $\mu=$ the overall mean, $S_{i}=$ the random site effect, $M_{j}=$ the fixed material effect, $(S M)_{i j}=$ the random interaction of material and site, $B(S)_{k(i)}=$ the random replicate effect of within site, and $e_{i j k}=$ the residual effect. Again SAS PROC MIXED was used separately for each arthropod damage endpoint in the analysis. The minimum and maximum mean values (reference range) were established from commercially available conventional reference hybrids to provide arthropod abundance or damage values representative of the natural variability within conventional maize for each arthropod.

\section{Data interpretation method}

Statistically significant differences between MON 87411 and conventional control were assessed for biological significance in the context of the range of 
the commercial reference hybrids, and for consistency with other collection methods, collection times ( $S$. frugiperda only), and/or sites. Statistically significant differences for which MON 87411 mean values were within the reference range, or that were not consistently detected using multiple collection methods, or not consistently observed in environments in which the same arthropod taxa occurred, were not considered biologically meaningful in terms of adverse environmental impact.

\section{Results and discussion}

An ERA of GM crops is conducted on a case-by-case basis using a weight of evidence approach and considering all relevant information. For the insectprotected GM crops, a step-wise, tiered testing approach using surrogate species is used since it is the recommended procedure to assess for potential effects on non-target organisms in many regulatory frameworks (Romeis et al. 2008, 2013). In the earliest tier, a battery of key arthropods with both agricultural and worldwide relevance is tested at doses of a test material (e.g. purified protein or dsRNA) well above those typically expressed in the plant. If the results of the first-tier studies require refinement, then highertiered testing may be conducted to address uncertainty in the risk assessment under progressively more realistic situations, and ultimately under field conditions if needed. In the case of insecticidal traits (DvSnf7 and Cry3Bb1) expressed in MON 87411, the tiered testing has not progressed beyond the early tiers due to the restricted activity spectrum of these traits (Palmer and Krueger 1999; Sinderman et al. 2002; Duan et al. 2008a, b; Li et al. 2008, 2010; Bachman et al. 2013). However, field studies to evaluate the effects of Cry3Bb1 on NTAs have been conducted and revealed no adverse effects to non-target arthropods (Ahmad et al. 2006; Bhatti et al. 2005a, b; Rauschen et al. 2010a, b; Rosca and Cagan 2012a, b; Svobodova et al. 2012a, b). To complement the portion of the NTA risk assessment focusing on adverse environmental effects, NTA field evaluations conducted as a part of plant characterization were also used to confirm findings from the lower-tier laboratory testing. We conducted a comprehensive field evaluation across three distinct geographic regions to understand how the NTAs that are most closely associated with the plant may respond to the introduction of MON 87411.

NTA abundance

Across all regions, a total of 128 individual-site statistical comparisons were made between MON 87411 and the conventional control for arthropod abundance representing 20 taxa including: antlike flower beetle, Notoxus monodon (Coleoptera: Anthicidae); aphid, several spp. (Homoptera: Aphididae); big-eyed bug, Geocoris spp. (Hemiptera: Geocoridae); corn flea beetle, Chaetocnema pulicaria (Coleoptera: Chrysomelidae); cornsilk fly, Euxesta stigmatias (Diptera: Otitidae); predatory earwig (Dermaptera: Forficulidae); delphacid planthopper (Delphacidae); lacewing, Chrysoperla spp. (Neuroptera: Chrysopidae); ladybird beetle, several spp. (Coleoptera: Coccinellidae); leafhopper, Dalbulus maidis (Homoptera: Cicadellidae); long-legged fly, Dolichopus spp. (Diptera: Dolichopodidae); Maecolapsis sp. (Coleoptera; Chrysomelidae); minute pirate bug, Orius insidiosus (Hemiptera: Anthocoridae); parasitic wasp, several spp. (Hymenoptera); predatory ground beetle, several spp. (Coleptera: Carabidae); sap beetle, several spp. (Coleoptera: Nitidulidae); shining flower beetle, Phalacrus politus (Coleoptera: Phalacridae); spider, several spp. (Araneae); spotted maize beetle, Astylus atromaculatus (Coleoptera: Melyridae); and hover fly, Toxomerus spp. (Syrphidae) (Tables 2, 3, 4). Lack of sufficient arthropod abundance precluded statistical comparisons between MON 87411 and the conventional control for 108 additional comparisons; however, descriptive statistics were provided for these comparisons (Supplementary material).

Across all three regions, no statistically significant differences were detected between MON 87411 and the conventional control for 123 of the 128 comparisons $(96.1 \%)$. In the U.S., statistically significant differences were detected in two taxa; aphid and ladybird beetle (Table 2). The mean abundance of aphids associated with MON 87411 was higher than the conventional control at one of the two sites where aphids were observed $(P=0.0132)$. However, the mean value for aphid abundance associated with MON 87411 was within the range of the commercial reference hybrids (MON 87411 mean $=5.1$ per plot; reference range 4.9-7.5 per plot). The mean abundance 
Table 2 Abundance of arthropods (Mean/Plot) determined using sticky traps and visual counts for MON 87411, conventional control, and references in 2012 US Field Trials

\begin{tabular}{|c|c|c|c|c|c|}
\hline \multirow[t]{2}{*}{ Arthropod $^{1}$} & \multirow[t]{2}{*}{ Primary role } & \multirow[t]{2}{*}{ Site } & \multicolumn{2}{|l|}{ Mean $\pm \mathrm{SE}^{2}$} & \multirow[t]{2}{*}{ Reference range } \\
\hline & & & MON 87411 & Control & \\
\hline \multicolumn{6}{|l|}{ Sticky traps } \\
\hline \multirow[t]{2}{*}{ Aphid (Aphididae) } & Herbivore & IABG & $3.2 \pm 0.95$ & $1.2 \pm 0.34$ & $2.1-5.1$ \\
\hline & & NEYO & $5.1 \pm 1.03^{*}$ & $4.1 \pm 1.41$ & $4.9-7.5$ \\
\hline \multirow[t]{2}{*}{ Corn flea beetle (Chrysomelidae) } & Herbivore & NCBD & $1.1 \pm 0.30$ & $2.7 \pm 0.88$ & $1.2-14.4$ \\
\hline & & PAHM & $5.7 \pm 2.48$ & $4.7 \pm 1.21$ & $6.5-15.6$ \\
\hline \multirow[t]{3}{*}{ Delphacid planthopper (Delphacidae) } & Herbivore & IABG & $0.7 \pm 0.41$ & $0.8 \pm 0.35$ & $1.4-1.8$ \\
\hline & & NCBD & $15.4 \pm 1.65$ & $18.2 \pm 1.95$ & $23.2-30.3$ \\
\hline & & PAHM & $4.6 \pm 1.10$ & $3.1 \pm 0.82$ & $2.4-8.3$ \\
\hline \multirow[t]{2}{*}{ Lacewing (Chrysopidae) } & Predator & IABG & $4.1 \pm 0.53$ & $4.4 \pm 0.45$ & $3.8-6.2$ \\
\hline & & NEYO & $1.7 \pm 0.30$ & $1.1 \pm 0.19$ & $1.1-3.2$ \\
\hline \multirow[t]{3}{*}{ Ladybird beetle (Coccinellidae) } & Predator & IABG & $1.1 \pm 0.17$ & $1.0 \pm 0.50$ & $1.3-3.8$ \\
\hline & & NCBD & $5.4 \pm 0.78$ & $6.5 \pm 0.60$ & $5.1-6.4$ \\
\hline & & PAHM & $17.6 \pm 3.00^{*}$ & $14.2 \pm 1.10$ & $13.1-16.8$ \\
\hline \multirow[t]{2}{*}{ Leafhopper (Cicadellidae) } & Herbivore & NCBD & $32.8 \pm 4.42$ & $35.9 \pm 7.82$ & $34.8-54.9$ \\
\hline & & PAHM & $3.7 \pm 0.87$ & $3.9 \pm 0.33$ & $3.4-8.6$ \\
\hline \multirow[t]{3}{*}{ Minute pirate bug (Anthocoridae) } & Predator & IABG & $0.9 \pm 0.42$ & $1.6 \pm 0.26$ & $1.9-4.7$ \\
\hline & & NCBD & $1.0 \pm 0.24$ & $0.7 \pm 0.15$ & $1.2-1.5$ \\
\hline & & PAHM & $2.0 \pm 0.53$ & $2.2 \pm 0.64$ & $3.6-6.2$ \\
\hline \multirow[t]{4}{*}{ Parasitic wasp (Hymenoptera) } & Parasitoid & IABG & $32.9 \pm 4.59$ & $36.1 \pm 3.82$ & $38.6-76.4$ \\
\hline & & NCBD & $89.4 \pm 9.09$ & $84.9 \pm 12.02$ & $122.7-139.0$ \\
\hline & & NEYO & $12.7 \pm 0.73$ & $12.4 \pm 0.93$ & $12.6-30.4$ \\
\hline & & PAHM & $122.3 \pm 18.70$ & $104.8 \pm 5.66$ & $116.0-159.5$ \\
\hline \multirow[t]{2}{*}{ Spider (Araneae) } & Predator & NCBD & $1.8 \pm 0.14$ & $1.5 \pm 0.53$ & $2.1-2.4$ \\
\hline & & PAHM & $1.9 \pm 0.52$ & $0.9 \pm 0.13$ & $1.1-1.5$ \\
\hline \multicolumn{6}{|l|}{ Visual counts } \\
\hline Ant-like flower beetle (Anthicidae) & Pollen feeder & IABG & $1.1 \pm 0.21$ & $2.4 \pm 0.92$ & $1.4-2.1$ \\
\hline \multirow[t]{2}{*}{ Corn flea beetle (Chrysomelidae) } & Herbivore & NCBD & $1.0 \pm 0.44$ & $1.8 \pm 1.01$ & $0.4-2.3$ \\
\hline & & PAHM & $6.5 \pm 1.38$ & $5.8 \pm 0.64$ & $6.6-7.9$ \\
\hline \multirow[t]{2}{*}{ Ladybird beetle (Coccinellidae) } & Predator & NCBD & $1.7 \pm 0.30$ & $1.2 \pm 0.05$ & $1.1-1.7$ \\
\hline & & PAHM & $2.3 \pm 0.29$ & $2.9 \pm 0.93$ & $1.5-1.8$ \\
\hline \multirow[t]{3}{*}{ Minute pirate bug (Anthocoridae) } & Predator & IABG & $2.1 \pm 0.16$ & $1.8 \pm 0.26$ & $1.4-2.3$ \\
\hline & & NCBD & $1.2 \pm 0.17$ & $1.0 \pm 0.8$ & $0.8-1.4$ \\
\hline & & PAHM & $4.4 \pm 0.92$ & $7.5 \pm 1.25$ & $4.7-7.8$ \\
\hline \multirow[t]{4}{*}{ Sap beetle (Nitidulidae) } & Herbivore & IABG & $6.6 \pm 2.23$ & $7.1 \pm 3.14$ & $2.3-5.0$ \\
\hline & & NCBD & $3.3 \pm 0.70$ & $3.2 \pm 0.85$ & $3.1-4.5$ \\
\hline & & NEYO & $2.7 \pm 0.36$ & $3.0 \pm 0.43$ & $1.3-1.6$ \\
\hline & & PAHM & $4.1 \pm 0.41$ & $3.7 \pm 1.16$ & $2.4-4.2$ \\
\hline \multirow[t]{2}{*}{ Shining flower beetle (Phalacridae) } & Pollen feeder & NCBD & $4.4 \pm 0.34$ & $5.0 \pm 1.02$ & $3.4-6.2$ \\
\hline & & PAHM & $1.3 \pm 0.33$ & $2.3 \pm 0.13$ & $1.1-1.7$ \\
\hline \multirow[t]{2}{*}{ Spider (Araneae) } & Predator & NCBD & $4.9 \pm 1.13$ & $3.9 \pm 0.22$ & $3.5-4.9$ \\
\hline & & PAHM & $1.5 \pm 0.58$ & $1.2 \pm 0.35$ & $1.4-2.4$ \\
\hline
\end{tabular}

* Indicates statistically significant difference between MON 87411 and the conventional control $(\alpha=0.05)$

1 Arthropods that met the minimum abundance criteria are included in the analysis

2 MON 87411 and the conventional control values represent means with standard error. $\mathrm{N}=4$

3 Reference range is calculated from the minimum and maximum mean values from among reference materials at each site 
Table 3 Abundance of arthropods (Mean/Plot) determined using sticky traps and visual counts for MON 87411, conventional control, and references in 2012-2013 Argentina Field Trials

\begin{tabular}{|c|c|c|c|c|c|}
\hline \multirow[t]{2}{*}{ Arthropod $^{1}$} & \multirow[t]{2}{*}{ Primary role } & \multirow[t]{2}{*}{ Site } & \multicolumn{2}{|l|}{ Mean \pm S.E. $^{2}$} & \multirow[t]{2}{*}{ Reference range $^{3}$} \\
\hline & & & MON 87411 & Control & \\
\hline \multicolumn{6}{|l|}{ Sticky traps } \\
\hline Aphid (Aphididae) & Herbivore & BAGH & $5.0 \pm 0.61$ & $5.5 \pm 1.06$ & $5.2-6.1$ \\
\hline \multirow[t]{3}{*}{ Lacewing (Chrysopidae) } & Predator & BAFE & $2.7 \pm 0.56$ & $1.9 \pm 0.33$ & $2.2-3.5$ \\
\hline & & BAGH & $1.8 \pm 0.57$ & $1.5 \pm 0.73$ & $2.6-3.8$ \\
\hline & & ERMY & $0.8 \pm 0.24$ & $1.0 \pm 0.25$ & $0.8-1.8$ \\
\hline \multirow[t]{3}{*}{ Ladybird beetle (Coccinellidae) } & Predator & BAFE & $5.9 \pm 0.68$ & $6.2 \pm 0.99$ & $3.8-7.9$ \\
\hline & & BAGH & $1.8 \pm 0.25$ & $1.7 \pm 0.32$ & $1.4-2.3$ \\
\hline & & TMBU & $1.0 \pm 0.08$ & $0.9 \pm 0.47$ & $1.2-1.8$ \\
\hline \multirow[t]{3}{*}{ Leafhopper (Cicadellidae) } & Herbivore & BAGH & $6.5 \pm 0.41$ & $6.2 \pm 0.50$ & $7.7-11.8$ \\
\hline & & ERMY & $2.6 \pm 0.29$ & $2.2 \pm 0.60$ & $2.0-3.9$ \\
\hline & & TMBU & $23.7 \pm 5.14$ & $22.8 \pm 6.37$ & $19.0-25.6$ \\
\hline \multirow[t]{3}{*}{ Spotted maize beetle (Melyridae) } & Herbivore & BAGH & $1.1 \pm 0.75$ & $0.9 \pm 0.36$ & $0.3-3.2$ \\
\hline & & ERMY & $1.4 \pm 0.16$ & $3.4 \pm 2.37$ & $1.1-2.9$ \\
\hline & & TMBU & $8.1 \pm 1.74$ & $9.1 \pm 1.16$ & $8.7-11.2$ \\
\hline \multirow[t]{2}{*}{ Minute pirate bug (Anthocoridae) } & Predators & BAFE & $8.1 \pm 0.54$ & $6.4 \pm 0.57$ & $9.6-12.6$ \\
\hline & & BAGH & $4.6 \pm 0.74$ & $5.5 \pm 0.35$ & $7.3-9.9$ \\
\hline \multirow[t]{2}{*}{ Parasitic wasp (Hymenoptera) } & Parasitoid & ERMY & $3.4 \pm 0.50$ & $2.9 \pm 0.29$ & $3.9-4.6$ \\
\hline & & TMBU & $21.2 \pm 2.72$ & $17.1 \pm 1.82$ & $14.2-23.0$ \\
\hline \multirow[t]{3}{*}{ Sap beetle (Nitidulidae) } & Herbivore & BAGH & $2.1 \pm 0.29$ & $2.9 \pm 0.58$ & $2.5-3.8$ \\
\hline & & ERMY & $2.4 \pm 0.81$ & $2.1 \pm 0.24$ & $1.3-3.7$ \\
\hline & & TMBU & $1.3 \pm 0.33$ & $1.3 \pm 0.09$ & $1.3-2.0$ \\
\hline Hover fly (Syrphidae) & Predator & BAGH & $1.1 \pm 0.09$ & $1.1 \pm 0.15$ & $1.3-2.3$ \\
\hline \multicolumn{6}{|l|}{ Visual counts } \\
\hline Aphid (Aphididae) & Herbivore & BAFE & $15.7 \pm 8.90$ & $6.5 \pm 2.88$ & $2.2-41.0$ \\
\hline \multirow[t]{4}{*}{ Predatory earwig (Forficulidae) } & Predator & BAFE & $35.2 \pm 4.40$ & $41.2 \pm 3.95$ & $23.7-41.8$ \\
\hline & & BAGH & $16.0 \pm 1.25$ & $11.3 \pm 1.22$ & $12.5-17.7$ \\
\hline & & ERMY & $2.0 \pm 0.28$ & $1.5 \pm 0.25$ & $1.2-1.9$ \\
\hline & & TMBU & $22.8 \pm 4.04$ & $31.7 \pm 2.01$ & $21.8-35.8$ \\
\hline \multirow[t]{4}{*}{ Lacewing (Chrysopidae) } & Predator & BAFE & $2.6 \pm 0.25$ & $2.4 \pm 0.31$ & $2.0-3.3$ \\
\hline & & BAGH & $1.3 \pm 0.17$ & $1.3 \pm 0.16$ & $1.0-1.4$ \\
\hline & & ERMY & $1.4 \pm 0.35$ & $1.5 \pm 0.12$ & $1.5-2.8$ \\
\hline & & TMBU & $1.0 \pm 0.18$ & $1.5 \pm 0.32$ & $1.1-1.8$ \\
\hline \multirow[t]{2}{*}{ Ladybird beetle (Coccinellidae) } & Predator & BAFE & $1.4 \pm 0.79$ & $1.0 \pm 0.37$ & $1.3-3.7$ \\
\hline & & TMBU & $0.4 \pm 0.08$ & $1.0 \pm 0.20$ & $1.2-1.5$ \\
\hline \multirow[t]{4}{*}{ Spotted maize beetle (Melyridae) } & Herbivore & BAFE & $8.1 \pm 3.40$ & $2.8 \pm 0.52$ & $3.2-36.9$ \\
\hline & & BAGH & $8.8 \pm 3.43^{*}$ & $4.9 \pm 1.42$ & $3.8-7.6$ \\
\hline & & ERMY & $2.3 \pm 0.74$ & $2.7 \pm 0.82$ & $0.5-14.7$ \\
\hline & & TMBU & $7.6 \pm 3.16$ & $4.4 \pm 0.82$ & $4.1-12.6$ \\
\hline \multirow[t]{4}{*}{ Minute pirate bugs (Anthocoridae) } & Predator & BAFE & $10.4 \pm 1.63$ & $11.4 \pm 1.07$ & $9.3-13.3$ \\
\hline & & BAGH & $7.8 \pm 0.55$ & $7.4 \pm 0.55$ & $7.8-9.4$ \\
\hline & & ERMY & $3.1 \pm 0.53$ & $3.4 \pm 0.63$ & $2.3-3.6$ \\
\hline & & TMBU & $3.2 \pm 0.62$ & $4.3 \pm 0.81$ & $3.8-5.0$ \\
\hline
\end{tabular}


Table 3 continued

\begin{tabular}{|c|c|c|c|c|c|}
\hline \multirow[t]{2}{*}{ Arthropod $^{1}$} & \multirow[t]{2}{*}{ Primary role } & \multirow[t]{2}{*}{ Site } & \multicolumn{2}{|l|}{ Mean \pm S.E. $^{2}$} & \multirow[t]{2}{*}{ Reference range ${ }^{3}$} \\
\hline & & & MON 87411 & Control & \\
\hline Parasitic wasp (Hymenoptera) & Parasitoid & BAGH & $3.3 \pm 0.18$ & $3.3 \pm 0.48$ & $3.2-3.8$ \\
\hline \multirow[t]{4}{*}{ Sap beetle (Nitidulidae) } & \multirow[t]{4}{*}{ Herbivore } & BAFE & $8.8 \pm 0.73$ & $8.6 \pm 2.19$ & $6.2-8.6$ \\
\hline & & BAGH & $11.5 \pm 1.79$ & $11.3 \pm 0.67$ & $10.0-13.4$ \\
\hline & & ERMY & $3.0 \pm 0.69$ & $3.8 \pm 0.32$ & $2.4-5.0$ \\
\hline & & TMBU & $3.5 \pm 1.43$ & $2.3 \pm 0.58$ & $1.0-8.2$ \\
\hline \multirow[t]{3}{*}{ Spider (Araneae) } & \multirow[t]{3}{*}{ Predator } & BAFE & $3.0 \pm 0.28$ & $3.4 \pm 0.57$ & $2.7-3.4$ \\
\hline & & BAGH & $2.1 \pm 0.25$ & $2.1 \pm 0.20$ & $1.7-2.5$ \\
\hline & & TMBU & $3.8 \pm 0.30$ & $3.5 \pm 0.29$ & $3.8-5.8$ \\
\hline
\end{tabular}

\footnotetext{
* Indicates statistically significant difference between MON 87411 and the conventional control $(\alpha=0.05)$

1 Arthropods that met the minimum abundance criteria are included in the analysis

2 MON 87411 and the conventional control values represent means with standard error. $\mathrm{N}=4$

3 Reference range is calculated from the minimum and maximum mean values from among reference materials at each site
}

of ladybird beetles was higher for MON 87411 than the conventional control at one of the three sites where ladybird beetles were observed. The mean abundance value for ladybird beetles associated with MON 87411 was slightly outside the range of the commercial reference hybrids $(\mathrm{MON} 87411$ mean $=17.6$ per plot; reference range 13.1-16.8 per plot). In Argentina, a single statistically significant difference was detected where MON 87411 had higher spotted maize beetle abundance compared to the conventional control at one of the four sites where spotted maize beetle was observed $(P=0.0345)$ (Table 3$)$. The mean abundance value for spotted maize beetle on MON 87411 was slightly outside the range of the commercial reference hybrids (MON 87411 mean $=8.8$ per plot; reference range 3.8-7.6 per plot). In Brazil, statistically significant differences were detected in two taxa; cornsilk fly and predatory earwig (Table 4). The mean abundance of cornsilk fly associated with MON 87411 was higher than the conventional control at one of the six sites where cornsilk fly was observed $(P=0.0014)$. The mean abundance value for cornsilk fly associated with MON 87411 was slightly outside the range of the commercial reference hybrids (MON 87411 mean $=54.3$ per plot; reference range $38.3-47.3$ per plot). The mean abundance of predatory earwig was lower for MON 87411 than the conventional control at one of the three sites where predatory earwig was observed. $(\mathrm{P}=0.005)$. However, the mean value of predatory earwig abundance on MON
87411 was within the range of commercial reference hybrids $($ MON 87411 mean $=2.8$ per plot; reference range $2.5-5.0$ per plot).

In each case where no differences were detected or where differences were detected in NTA abundance, the mean value for MON 87411 was within the reference range and/or the difference was not consistently observed across collection methods and/or sites. Thus, these differences were not indicative of a consistent response associated with the trait and are not considered biologically meaningful in terms of adverse environmental impact of MON 87411 compared to conventional maize.

A high degree of similarity of taxa across regions was observed especially for the most abundant taxa representing the ecological functions of herbivores, predators and parasitoids in maize fields: aphid, predatory earwig, lacewing, ladybird beetle, leafhopper, minute pirate bug, parasitic wasp, sap beetle, and spider. For the nine widely distributed taxa, no statistically significant differences in their abundance were detected between MON 87411 and the conventional control (Table 5). A retrospective power analysis of the data indicated that population-level effects of $50 \%$ were detectable with $80 \%$ power for the widely distributed taxa across regions (Table 5). Therefore, given the scale and intensity of the sampling, any significant impacts of MON 87411 maize on populations of widely distributed taxa should have been detectable within this study. 
Table 4 Abundance of Arthropods (Mean/Plot) Determined Using Sticky Traps and Visual Counts for MON 87411, Conventional Control, and References in 2013-14 Brazil Field Trials

\begin{tabular}{|c|c|c|c|c|c|}
\hline \multirow[t]{2}{*}{ Arthropod $^{1}$} & \multirow[t]{2}{*}{ Primary role } & \multirow[t]{2}{*}{ Site } & \multicolumn{2}{|l|}{ Mean \pm S.E. $^{2}$} & \multirow[t]{2}{*}{ Reference range $^{3}$} \\
\hline & & & MON 87411 & Control & \\
\hline \multicolumn{6}{|l|}{ Sticky traps } \\
\hline Big-eyed bug (Geocoridae) & Predator & SPSD & $5.8 \pm 1.21$ & $4.0 \pm 0.92$ & $2.0-4.7$ \\
\hline \multirow[t]{6}{*}{ Cornsilk fly (Otitidae) } & \multirow[t]{6}{*}{ Herbivore } & BALM & $210.3 \pm 33.77$ & $244.5 \pm 30.91$ & $201.8-294.8$ \\
\hline & & $\mathrm{MGCH}$ & $54.3 \pm 2.56^{*}$ & $36.5 \pm 2.63$ & $38.3-47.3$ \\
\hline & & MTSO & $377.1 \pm 28.46$ & $296.6 \pm 18.40$ & $232.7-327.8$ \\
\hline & & PRRO & $244.7 \pm 19.45$ & $252.1 \pm 21.70$ & $139.9-336.3$ \\
\hline & & RSNM & $291.7 \pm 44.89$ & $301.9 \pm 29.78$ & $172.3-219.6$ \\
\hline & & SPSD & $230.8 \pm 21.81$ & $196.8 \pm 15.32$ & $163.0-227.8$ \\
\hline \multirow[t]{3}{*}{ Predatory earwig (Forficulidae) } & \multirow[t]{3}{*}{ Predator } & MTSO & $2.8 \pm 0.63^{*}$ & $5.4 \pm 2.14$ & $2.5-5.0$ \\
\hline & & PRRO & $6.6 \pm 1.38$ & $5.5 \pm 1.49$ & $4.8-6.6$ \\
\hline & & RSNM & $3.3 \pm 0.81$ & $4.1 \pm 0.44$ & $3.3-5.2$ \\
\hline Lacewing (Chrysopidae) & Predator & MGCH & $1.0 \pm 0.16$ & $1.3 \pm 0.09$ & $0.9-1.5$ \\
\hline \multirow[t]{2}{*}{ Ladybird beetle (Coccinellidae) } & \multirow[t]{2}{*}{ Predator } & $\mathrm{MGCH}$ & $2.6 \pm 0.36$ & $2.4 \pm 0.67$ & $0.9-2.1$ \\
\hline & & SPSD & $2.9 \pm 0.88$ & $2.6 \pm 0.52$ & $1.3-1.9$ \\
\hline \multirow[t]{6}{*}{ Leafhopper (Cicadellidae) } & \multirow[t]{6}{*}{ Herbivore } & BALM & $1008.6 \pm 129.72$ & $942.4 \pm 93.50$ & $851.5-1170$ \\
\hline & & $\mathrm{MGCH}$ & $114.2 \pm 2.53$ & $108.6 \pm 2.84$ & $108.3-125.9$ \\
\hline & & MTSO & $27.2 \pm 3.45$ & $21.1 \pm 2.37$ & $14.3-26.0$ \\
\hline & & PRRO & $26.1 \pm 1.08$ & $31.3 \pm 1.99$ & $20.1-25.3$ \\
\hline & & RSNM & $34.0 \pm 4.44$ & $40.7 \pm 8.11$ & $38.8-48.4$ \\
\hline & & SPSD & $200.7 \pm 22.24$ & $164.2 \pm 12.74$ & $131.7-163.3$ \\
\hline Long legged fly (Dolichopodidae) & Predator & PRRO & $5.1 \pm 1.45$ & $5.8 \pm 1.41$ & $2.9-6.6$ \\
\hline Maecolapsis sp. (Chrysomelidae) & Herbivore & $\mathrm{MGCH}$ & $3.3 \pm 0.40$ & $3.3 \pm 0.33$ & $1.8-4.3$ \\
\hline \multirow[t]{3}{*}{ Minute pirate bug (Anthocoridae) } & \multirow[t]{3}{*}{ Predator } & PRRO & $4.7 \pm 0.78$ & $7.0 \pm 0.95$ & $3.4-6.6$ \\
\hline & & RSNM & $17.2 \pm 2.08$ & $13.8 \pm 2.66$ & $9.8-15.1$ \\
\hline & & SPSD & $9.5 \pm 1.05$ & $8.6 \pm 1.81$ & $5.7-7.1$ \\
\hline Predatory ground beetle (Carabidae) & Predators & RSNM & $2.7 \pm 0.85$ & $2.6 \pm 0.43$ & $0.7-2.0$ \\
\hline Spider (Araneae) & Predator & MTSO & $1.7 \pm 0.31$ & $2.5 \pm 0.31$ & $1.7-2.3$ \\
\hline \multicolumn{6}{|l|}{ Visual counts } \\
\hline Big-eyed bug (Geocoridae) & Predator & SPSD & $1.9 \pm 0.26$ & $0.9 \pm 0.19$ & $0.9-1.4$ \\
\hline \multirow[t]{6}{*}{ Predatory earwig (Forficulidae) } & \multirow[t]{6}{*}{ Predator } & BALM & $0.9 \pm 0.13$ & $1.7 \pm 0.64$ & $1.2-2.4$ \\
\hline & & $\mathrm{MGCH}$ & $3.0 \pm 0.48$ & $2.7 \pm 0.34$ & $2.9-3.6$ \\
\hline & & MTSO & $2.4 \pm 0.54$ & $2.6 \pm 0.09$ & $3.5-4.3$ \\
\hline & & PRRO & $13.5 \pm 1.32$ & $13.3 \pm 1.28$ & $14.0-14.8$ \\
\hline & & RSNM & $4.0 \pm 0.22$ & $4.4 \pm 0.54$ & $4.0-5.3$ \\
\hline & & SPSD & $2.4 \pm 0.75$ & $1.9 \pm 0.21$ & $1.9-3.2$ \\
\hline Ladybird beetle (Coccinellidae) & Predator & SPSD & $1.4 \pm 0.09$ & $0.9 \pm 0.15$ & $1.2-1.4$ \\
\hline \multirow[t]{2}{*}{ Minute pirate bug (Anthocoridae) } & \multirow[t]{2}{*}{ Predator } & RSNM & $1.6 \pm 0.32$ & $1.8 \pm 0.49$ & $1.9-2.4$ \\
\hline & & SPSD & $2.7 \pm 0.35$ & $1.2 \pm 0.34$ & $1.0-2.2$ \\
\hline \multirow[t]{3}{*}{ Sap beetle (Nitidulidae) } & \multirow[t]{3}{*}{ Herbivore } & MTSO & $6.8 \pm 0.27$ & $6.0 \pm 0.27$ & $6.0-7.6$ \\
\hline & & PRRO & $9.3 \pm 0.64$ & $6.3 \pm 0.50$ & $6.3-18.6$ \\
\hline & & SPSD & $7.3 \pm 0.64$ & $6.3 \pm 0.50$ & $3.9-6.5$ \\
\hline
\end{tabular}


Table 4 continued

\begin{tabular}{lllllll}
\hline Arthropod $^{1}$ & Primary role & Site & \multicolumn{2}{l}{ Mean \pm S.E. } & \multicolumn{2}{c}{ Reference range $^{3}$} \\
\cline { 3 - 6 } & & & MON 87411 & Control \\
\hline Spider (Araneae) & Predator & MGCH & $1.3 \pm 0.38$ & $1.1 \pm 0.31$ & $1.0-1.2$ \\
& & SPSD & $3.0 \pm 0.40$ & $2.1 \pm 0.05$ & $2.5-2.7$ \\
\hline
\end{tabular}

* Indicates statistically significant difference between MON 87411 and the conventional control $(\alpha=0.05)$

1 Arthropods that met the minimum abundance criteria are included in the analysis

2 MON 87411 and the conventional control values represent means with standard error. $\mathrm{N}=4$

3 Reference range is calculated from the minimum and maximum mean values from among reference materials at each site

NTA damage

A total of 56 statistical comparisons were made between MON 87411 and the conventional control for plant damage caused by the following non-target arthropods: $O$. nubilalis, D. saccharalis, H. zea, and S. frugiperda. Across all three regions, no statistically significant differences were detected between MON 87411 and the conventional control for 53 of the 56 comparisons $(94.6 \%)$ (Tables 6, 7, 8, 9). Lack of variability in the data precluded statistical comparisons between MON 87411 and conventional control for one additional comparison; however, the mean for MON 87411 and the conventional control were the same value for this comparison, indicating no biological differences.
A total of three statistically significant differences involving two taxa were detected between MON 87411 and conventional control. In the U.S., MON 87411 had higher ear damage than conventional control from $H . z e a$ at one of the four sites $(P<0.05)$ (Table 6). In Argentina, MON 87411 had less leaf damage than conventional control from S. frugiperda in the third observation at one of the four sites $(P<0.05)$ (Tables 7, 8). In Brazil, MON 87411 had less ear damage than the conventional control from $H$. $z e a$ and $S$. frugiperda at one of the six sites $(P<0.05)$ (Table 9). In each case where a significant difference in NTA damage between MON 87411 and the conventional control was detected, mean values for MON 87411 were within the reference range and/or

Table 5 Abundance of Arthropods (Mean/Plot) Associated with MON 87411 and the Conventional Control in Field Trials Across Regions

\begin{tabular}{|c|c|c|c|c|c|c|}
\hline \multirow[t]{2}{*}{ Arthropod $^{1}$} & \multirow{2}{*}{$\begin{array}{l}\text { Number of } \\
\text { Regions }\end{array}$} & \multirow{2}{*}{$\begin{array}{l}\text { Number of Sites across } \\
\text { Regions }\end{array}$} & \multicolumn{2}{|l|}{ Mean } & \multirow[t]{2}{*}{$P$ Value } & \multirow{2}{*}{$\begin{array}{l}\text { Statistical Power } \\
(\%)^{2}\end{array}$} \\
\hline & & & MON 87411 & Control & & \\
\hline Aphid (Aphididae) & 2 & 4 & 7.2 & 4.3 & 0.279 & 73.1 \\
\hline $\begin{array}{l}\text { Predatory earwig } \\
\text { (Forficulidae) }\end{array}$ & 2 & 10 & 12.0 & 13.3 & 0.194 & 100.0 \\
\hline Lacewing (Chrysopidae) & 3 & 6 & 2.3 & 2.3 & 0.956 & 87.3 \\
\hline $\begin{array}{l}\text { Ladybird beetle } \\
\text { (Coccinellidae) }\end{array}$ & 3 & 8 & 4.9 & 4.6 & 0.496 & 100.0 \\
\hline Leafhopper (Cicadellidae) & 3 & 11 & 103.7 & 96.5 & 0.615 & 100.0 \\
\hline $\begin{array}{l}\text { Minute pirate bug } \\
\text { (Anthocoridae) }\end{array}$ & 3 & 10 & 8.1 & 8.2 & 0.990 & 100.0 \\
\hline $\begin{array}{l}\text { Parasitic wasp } \\
\text { (Hymenoptera) }\end{array}$ & 2 & 7 & 38.8 & 35.8 & 0.242 & 100.0 \\
\hline Sap beetle (Nitidulidae) & 3 & 11 & 6.6 & 6.7 & 0.778 & 100.0 \\
\hline Spider (Araneae) & 3 & 8 & 3.1 & 2.8 & 0.355 & 99.5 \\
\hline
\end{tabular}

1 Arthropods observed that were most abundant and similar across regions

2 Statistical power to detect a $50 \%$ difference in abundance between MON 87411 and control 
Table 6 Non-Target Arthropod Pest Damage to MON 87411, Conventional Control, and References in 2012 U.S. Field Trials

\begin{tabular}{|c|c|c|c|c|c|}
\hline \multirow[t]{2}{*}{ Non-target arthropod pest } & \multirow[t]{2}{*}{ Damage assessment } & \multirow[t]{2}{*}{ Site } & \multicolumn{2}{|l|}{ Mean \pm S.E. ${ }^{1}$} & \multirow[t]{2}{*}{ Reference range $^{2}$} \\
\hline & & & MON 87411 & Control & \\
\hline \multirow[t]{4}{*}{ H. zea } & \multirow{4}{*}{$\begin{array}{l}\text { Ear damage area of } \\
10 \text { plants per plot }\left(\mathrm{cm}^{2}\right)\end{array}$} & IABG & $0.7 \pm 0.38$ & $0.5 \pm 0.28$ & $0.5-1.3$ \\
\hline & & NCBD & $3.3 \pm 1.25^{*}$ & $1.5 \pm 0.39$ & $0.7-1.8$ \\
\hline & & NEYO & $3.2 \pm 0.13$ & $3.0 \pm 0.22$ & $2.3-3.2$ \\
\hline & & PAHM & $0.3 \pm 0.23$ & $0.2 \pm 0.11$ & $0.2-0.3$ \\
\hline \multirow[t]{4}{*}{ O. nubilalis } & \multirow{4}{*}{$\begin{array}{l}\text { Number of stalk galleries of } \\
10 \text { plants per plot }\end{array}$} & IABG & $0.0 \pm 0.03$ & $0.0 \pm 0.00$ & $0.0-0.1$ \\
\hline & & NCBD & $0.1 \pm 0.03$ & $0.1 \pm 0.04$ & $0.1-0.3$ \\
\hline & & NEYO & $0.0 \pm 0.00$ & $0.0 \pm 0.00$ & $0.0-0.0$ \\
\hline & & PAHM & $1.4 \pm 0.24$ & $1.8 \pm 0.33$ & $1.4-1.8$ \\
\hline \multirow[t]{4}{*}{ O. nubilalis } & \multirow{4}{*}{$\begin{array}{l}\text { Stalk gallery length }(\mathrm{cm}) \text { of } \\
10 \text { plants per plot }\end{array}$} & IABG & $0.1 \pm 0.08$ & $0.0 \pm 0.00$ & $0.0-0.3$ \\
\hline & & NCBD & $0.5 \pm 0.19$ & $0.2 \pm 0.14$ & $0.5-0.7$ \\
\hline & & NEYO & $0.0 \pm 0.00$ & $0.0 \pm 0.00$ & $0.0-0.1$ \\
\hline & & PAHM & $5.9 \pm 1.46$ & $7.9 \pm 1.46$ & $5.6-8.3$ \\
\hline
\end{tabular}

* Indicates a significant difference between MON 87411 and the conventional control $(\alpha=0.05)$ using ANOVA

1 MON 87411 and the conventional control values represent means with standard error in parentheses

2 Reference range is calculated from the minimum and maximum mean values from among four reference materials at each site

Table 7 Non-target arthropod pest damage to MON 87411, conventional control, and references in 2012-2013 Argentina Field Trials

\begin{tabular}{|c|c|c|c|c|c|}
\hline \multirow{2}{*}{$\begin{array}{l}\text { Non-Target } \\
\text { Arthropod Pest }\end{array}$} & \multirow[t]{2}{*}{ Damage assessment } & \multirow[t]{2}{*}{ Site } & \multicolumn{2}{|l|}{ Mean \pm S.E. ${ }^{1}$} & \multirow[t]{2}{*}{ Reference range $^{2}$} \\
\hline & & & MON 87411 & Control & \\
\hline \multirow[t]{4}{*}{ H. zea } & \multirow{4}{*}{$\begin{array}{l}\text { Ear damage area of } 10 \text { plants } \\
\text { per plot }\left(\mathrm{cm}^{2}\right)\end{array}$} & BAFE & $6.0 \pm 0.83$ & $6.1 \pm 0.53$ & $4.8-5.8$ \\
\hline & & BAGH & $14.2 \pm 1.32$ & $16.3 \pm 0.40$ & $8.0-18.7$ \\
\hline & & ERMY & $1.0 \pm 0.39$ & $1.0 \pm 0.28$ & $0.4-1.1$ \\
\hline & & TMBU & $1.0 \pm 0.25$ & $1.0 \pm 0.32$ & $0.7-1.3$ \\
\hline \multirow[t]{4}{*}{ D. saccharalis } & \multirow{4}{*}{$\begin{array}{l}\text { Number of stalk galleries of } 10 \\
\text { plants per plot }\end{array}$} & BAFE & $3.5 \pm 0.99$ & $4.4 \pm 0.53$ & $2.9-4.2$ \\
\hline & & BAGH & $2.6 \pm 0.28$ & $3.0 \pm 0.44$ & $2.3-3.0$ \\
\hline & & ERMY & $1.5 \pm 0.16$ & $1.1 \pm 0.30$ & $1.1-1.5$ \\
\hline & & TMBU & $0.3 \pm 0.16$ & $0.3 \pm 0.09$ & $0.2-0.5$ \\
\hline \multirow[t]{4}{*}{ D. saccharalis } & \multirow{4}{*}{$\begin{array}{l}\text { Stalk gallery length }(\mathrm{cm}) \text { of } 10 \\
\text { plants per plot }\end{array}$} & BAFE & $23.3 \pm 6.52$ & $27.9 \pm 4.24$ & $19.4-26.2$ \\
\hline & & BAGH & $15.6 \pm 2.86$ & $17.6 \pm 5.31$ & $12.9-19.3$ \\
\hline & & ERMY & $13.7 \pm 3.21$ & $9.8 \pm 2.84$ & $6.7-12.2$ \\
\hline & & TMBU & $2.3 \pm 1.36$ & $2.8 \pm 1.09$ & $1.3-5.5$ \\
\hline
\end{tabular}

difference between test and control were not consistently observed across observation times and/or sites (Tables 6, 7, 8, 9). Thus, these differences were not indicative of consistent plant responses associated with the insect-protected and glyphosate tolerant traits and are unlikely to be biologically meaningful in terms of increased adverse environmental impact of MON 87411 compared to conventional maize.
Representative taxa and data transportability

This study was conducted in diverse maize growing regions representative of temperate and tropical agroecological zones and assessed representative arthropods consistent with the representative taxa concept and surrogate species approach used for the NTA risk assessment of GM crops. The taxa evaluated were 
Table 8 Non-target arthropod pest damage to MON 87411, conventional control, and references in 2012-2013 Argentina Field Trials

\begin{tabular}{|c|c|c|c|c|c|c|}
\hline \multirow[t]{2}{*}{ Non-target arthropod pest } & \multirow[t]{2}{*}{ Damage assessment } & \multirow[t]{2}{*}{ Site } & \multirow[t]{2}{*}{ Observation number } & \multicolumn{2}{|c|}{ Mean \pm S.E. ${ }^{1}$} & \multirow[t]{2}{*}{ Reference range $^{2}$} \\
\hline & & & & MON 87411 & Control & \\
\hline \multirow[t]{15}{*}{ S. frugiperda } & \multirow{15}{*}{$\begin{array}{l}\text { Damage area of } \\
10 \text { plants per plot } \\
\text { (rating } 0-9 \text { ) }\end{array}$} & \multirow[t]{5}{*}{ BAFE } & 1 & $0.3 \pm 0.21$ & $0.2 \pm 0.14$ & $1.0-1.6$ \\
\hline & & & 2 & $0.5 \pm 0.28$ & $0.2 \pm 0.11$ & $0.4-1.0$ \\
\hline & & & 3 & $0.5 \pm 0.17$ & $0.6 \pm 0.19$ & $0.3-0.6$ \\
\hline & & & 4 & $0.2 \pm 0.13$ & $0.1 \pm 0.05$ & $0.1-0.3$ \\
\hline & & & 5 & $0.2 \pm 0.10$ & $0.1 \pm 0.08$ & $0.0-0.1$ \\
\hline & & \multirow[t]{2}{*}{ BAGH } & 1 & $0.6 \pm 0.33$ & $0.5 \pm 0.30$ & $1.6-1.8$ \\
\hline & & & 2 & $0.0 \pm 0.00^{\dagger}$ & $0.0 \pm 0.00^{\dagger}$ & $0.0-0.0$ \\
\hline & & \multirow[t]{5}{*}{ ERMY } & 1 & $1.5 \pm 0.38$ & $1.6 \pm 0.72$ & $1.9-3.0$ \\
\hline & & & 2 & $4.1 \pm 0.39$ & $3.4 \pm 0.38$ & $3.6-5.7$ \\
\hline & & & 3 & $4.9 \pm 0.36$ & $3.6 \pm 0.50$ & $2.5-4.1$ \\
\hline & & & 4 & $3.4 \pm 0.80$ & $3.5 \pm 1.15$ & $1.7-3.9$ \\
\hline & & & 5 & $3.9 \pm 0.96$ & $2.8 \pm 0.64$ & $1.7-2.7$ \\
\hline & & \multirow[t]{3}{*}{ TMBU } & 1 & $0.2 \pm 0.11$ & $0.2 \pm 0.08$ & $0.4-1.4$ \\
\hline & & & 2 & $1.5 \pm 0.22$ & $1.6 \pm 0.24$ & $1.9-2.3$ \\
\hline & & & 3 & $1.5 \pm 0.30 *$ & $2.2 \pm 0.17$ & $1.3-2.0$ \\
\hline
\end{tabular}

Table 9 Non-target arthropod pest damage to MON 87411, conventional control, and references in 2013-2014 Brazil Field Trials

\begin{tabular}{|c|c|c|c|c|c|}
\hline \multirow{2}{*}{$\begin{array}{l}\text { Non-target } \\
\text { arthropod pest }\end{array}$} & \multirow[t]{2}{*}{ Damage assessment } & \multirow[t]{2}{*}{ Site } & \multicolumn{2}{|l|}{ Mean \pm S.E. ${ }^{1}$} & \multirow[t]{2}{*}{ Reference range $^{2}$} \\
\hline & & & MON 87411 & Control & \\
\hline \multirow[t]{6}{*}{ H. zea and S. frugiperda } & \multirow{6}{*}{$\begin{array}{l}\text { Ear damage area of } \\
10 \text { plants per plot }\left(\mathrm{cm}^{2}\right)\end{array}$} & BALM & $5.3 \pm 0.96$ & $4.6 \pm 1.52$ & $0.5-1.6$ \\
\hline & & $\mathrm{MGCH}$ & $1.0 \pm 0.29$ & $0.8 \pm 0.35$ & $0.0-1.1$ \\
\hline & & MTSO & $1.2 \pm 0.36$ & $1.1 \pm 0.31$ & $0.3-0.7$ \\
\hline & & PRRO & $2.3 \pm 0.72$ & $3.4 \pm 0.31$ & $1.8-4.1$ \\
\hline & & RSNM & $10.3 \pm 1.31$ & $11.5 \pm 1.59$ & $4.9-9.7$ \\
\hline & & SPSD & $1.9 \pm 0.36^{*}$ & $3.3 \pm 0.43$ & $1.0-1.7$ \\
\hline \multirow[t]{6}{*}{ S. frugiperda } & \multirow{6}{*}{$\begin{array}{l}\text { Damage area of } \\
10 \text { plants per plot (rating 0-9) }\end{array}$} & BALM & $7.1 \pm 0.66$ & $5.9 \pm 0.54$ & $4.8-6.8$ \\
\hline & & $\mathrm{MGCH}$ & $0.8 \pm 0.35$ & $0.6 \pm 0.17$ & $0.4-0.7$ \\
\hline & & MTSO & $2.9 \pm 0.19$ & $3.3 \pm 0.42$ & $2.6-3.2$ \\
\hline & & PRRO & $3.0 \pm 0.42$ & $2.6 \pm 0.19$ & $2.2-2.5$ \\
\hline & & RSNM & $0.8 \pm 0.41$ & $1.4 \pm 0.46$ & $0.7-2.4$ \\
\hline & & SPSD & $3.6 \pm 0.22$ & $4.1 \pm 0.41$ & $4.0-4.5$ \\
\hline \multirow[t]{6}{*}{ D. saccharalis } & \multirow{6}{*}{$\begin{array}{l}\text { Stalk gallery length }(\mathrm{cm}) \text { of } \\
10 \text { plants per plot }\end{array}$} & BALM & $1.0 \pm 0.36$ & $0.7 \pm 0.23$ & $0.3-1.0$ \\
\hline & & $\mathrm{MGCH}$ & $1.3 \pm 0.34$ & $1.6 \pm 0.69$ & $3.3-12.9$ \\
\hline & & MTSO & $37.7 \pm 3.57$ & $35.4 \pm 5.09$ & $25.1-45.7$ \\
\hline & & PRRO & $2.0 \pm 1.41$ & $0.0 \pm 0.00$ & $0.7-4.2$ \\
\hline & & RSNM & $0.3 \pm 0.17$ & $0.1 \pm 0.050$ & $0.0-0.8$ \\
\hline & & SPSD & $0.3 \pm 0.18$ & $0.3 \pm 0.28$ & $0.0-0.3$ \\
\hline
\end{tabular}

\footnotetext{
* Indicates a significant difference between MON 87411 and the conventional control $(\alpha=0.05)$ using ANOVA

1 MON 87411 and the conventional control values represent means with standard error in parentheses

2 Reference range is calculated from the minimum and maximum mean values from among four reference materials at each site
} 
appropriate for use in this study because they had the potential for direct or indirect exposure to the trait, were sufficiently abundant, and were relevant for risk assessment (Garcia-Alonso et al. 2006; Rose 2006; Romeis et al. 2008, 2009, 2013). Since it is not practically possible to evaluate all the arthropods during field evaluation of NTAs, a "representative taxa concept" was utilized to focus on those taxa for which data can be reliably obtained and statistical robustness can be guaranteed (Knecht et al. 2010; Albajes et al. 2013; Carstens et al. 2014). The two most commonly used criteria for selection of representative taxa are consistency in abundance over the typical geographic range of the crop, and the suitability of taxa to detect small differences between the GM crop and its conventional comparator (Meissle et al. 2013; Albajes et al. 2013; Comas et al. 2013, 2014, 2015). In this study, we also provided further evidence for the adoption of the representative taxa concept for use in the environmental risk assessment of GM crops.

In the current assessments of NTA abundance, twenty arthropod taxa met minimum abundance criteria for statistical analysis. Nine of these taxa occurred in at least two of the three regions and in at least four sites across regions: aphid, predatory earwig, lacewing, ladybird beetle, leafhopper, minute pirate bug, parasitic wasp, sap beetle, and spider. In addition to wide regional distribution, these nine taxa fit the concept of representative taxa for field tests evaluating the impact of insect-protected maize on NTAs and encompass the ecological functions of herbivores, predators and parasitoids that would typically be subjected to above ground exposure of these traits. The nine taxa we identified also meet the recommendations of Knecht et al. (2010), Albajes et al. (2013), and Comas et al. (2013 and 2015) on abundance consistency and capacity to detect potential effects. A similar concept, the surrogate species approach has been used for tier 1 laboratory studies where indicator organisms are selected as representative taxa for hazard testing in an ERA (Garcia-Alonso et al. 2006; Romeis et al. 2011; Carstens et al. 2014). Surrogate species are typically chosen due to their relevance to the crop and amenability to testing in micro-environments (Barrett et al. 1994; Rose 2006; Romeis et al. 2008). The use of the surrogate species approach has allowed laboratory data generated on the effects of insecticidal traits on NTAs in one region, to be used in different regions, without necessarily repeating these studies.

Therefore, the nine taxa identified in our studies may serve as representative taxa in maize agroecosystems, indicating that the data are readily transportable for use in risk assessment between these geographic regions and to other regions with similar fauna. The beneficial impact of transportable data based on the similarity of NTAs in commercial maizegrowing regions indicates that repeated local field trials may not be necessary and may represent duplicated effort with limited value for the ERA of a GM crop. The few differences in taxa that may occur across geographies are not barriers to data transportability but require appropriate consideration in the context of problem formulation and tiered testing in the ERA.

\section{Conclusion}

Leveraging relevant transportable data across geographies for the ERA of GM crops can provide useful pertinent data to risk assessors and may result in significant time and cost savings by eliminating duplicated field work (Garcia-Alonso et al. 2014; Horak et al. 2015a, b; Nakai et al. 2015). Irrespective of variations in climate, region, and overall biodiversity of a given region, our results indicate high similarity across regions for important functional groups represented by herbivores, predatory and parasitic arthropod taxa closely associated with maize within agroecosystems where the crop is grown. This high degree of similarity of taxa across regions indicates that findings from one region are relevant, and thus transportable for use in the ERA of similar GM crop products in other regions.

The results of the NTA assessments in multi-site and multi-region field trials demonstrate the absence of adverse effects when NTA communities are exposed to maize MON 87411 expressing DvSnf7, Cry3Bb1, and CP4 EPSPS traits. Our results are in agreement with other studies that demonstrate the absence of adverse effects independently for Dvsnf7 (Bachman et al. 2013), Cry3Bb1 (Lundgren and Wiedenmann 2002; Al-Deeb and Wilde 2003; Ahmad et al. 2005, 2006; Bhatti et al. 2005a, b; Li and Romeis 2009, 2011; Devos et al. 2012; Comas et al. 2014; ILSI-CERA 2014), and CP4 EPSPS (Reyes 2005; 
Rosca 2004; Schier 2006; ILSI-CERA 2010; Comas et al. 2014). These field results confirm findings from the lower-tier laboratory testing by demonstrating no adverse effect on arthropod communities representing the ecological functions of herbivores, predators, and parasitoids in maize agro-ecosystems. Additionally, these NTA assessments provide further support for the extrapolation of laboratory results to the field.

Field data on NTAs obtained in this study for a CRW-protected GM maize were similar across diverse geographic regions in arthropod taxa representative of ecologically relevant taxonomic and functional groups. Therefore, along with pertinent laboratory data, appropriate plant characterization and NTA field data are relevant and transportable to other geographies for the ERA of the same GM crop, or related traits or GM crop/trait combinations where the ecological assessment endpoints are similar. It is important that regulators have access to and utilize environmental assessment data on the crop and trait that are generated in other geographies. Leveraging existing, relevant data for the ERA of GM crops across geographies will conserve resources, eliminate redundancy, and support conclusions with high certainty for assessing potential environmental risk from the commercial release of a GM crop.

Acknowledgments Thanks to Ernie Clawson, Kara Giddings, Christina Lawrence, Clara Rubinstein, Betiana Parody, and Pamela Bachman who gave constructive comments on an earlier draft of the MS. This research was supported by Monsanto Company.

Open Access This article is distributed under the terms of the Creative Commons Attribution 4.0 International License (http:// creativecommons.org/licenses/by/4.0/), which permits unrestricted use, distribution, and reproduction in any medium, provided you give appropriate credit to the original author(s) and the source, provide a link to the Creative Commons license, and indicate if changes were made.

\section{References}

Ahmad A, Wilde GE, Zhu KY (2005) Detectability of coleopteran-specific Cry3Bb1 protein in soil and its effect on non target surface and below-ground arthropods. Environ Entomol 34:385-394

Ahmad A, Wilde GE, Whitworth RJ, Zolnerowich G (2006) Effect of corn hybrids expressing the coleopteran-specific Cry3Bb1 protein for corn rootworm control on aboveground insect predators. J Econ Entomol 99:1085-1095
Albajes R, Lumbierres B, Pons X, Comas J (2013) Representative taxa in field trials for environmental risk assessment of genetically modified maize. Bull Entomol Res 103:724-733

Al-Deeb MA, Wilde GE (2003) Effect of Bt corn expressing the Cry3Bb1 toxin for corn rootworm control on aboveground non target arthropods. Environ Entomol 32:1164-1170

Bachman PM, Bolognesi R, Moar WJ, Mueller GM, Paradise MS, Ramaseshadri P, Tan J, Uffman JP, Warren J, Wiggins BE, Levine SL (2013) Characterization of the spectrum of insecticidal activity of a double-stranded RNA with targeted activity against Western Corn Rootworm (Diabrotica virgifera virgifera LeConte). Transgenic Res 22:12071222

Barrett K, Grandy N, Harrison EG, Hassan S, Oomen P (1994) Guidance document on regulatory testing procedures for pesticides with non-target arthropods. ESCORT Workgroup, Wageningen, The Netherlands 1994. Society of Environmental Toxicology and Chemistry-Europe (SETAC)

Bhatti MA, Duan J, Head G, Jiang C, McKee MJ, Nickson TE, Pilcher CL, Pilcher CD (2005a) Field evaluation of the impact of corn rootworm (Coleoptera: Chrysomelidae)protected Bt corn on ground-dwelling invertebrates. Environ Entomol 34:1325-1335

Bhatti MA, Duan J, Head G, Jiang C, McKee MJ, Nickson TE, Pilcher CL, Pilcher CD (2005b) Field evaluation of the impact of corn rootworm (Coleoptera: Chrysomelidae)protected Bt corn on foliage-dwelling arthropods. Environ Entomol 34:1336-1345

Bolognesi R, Ramaseshadri P, Anderson J, Bachman P, Clinton W, Flannagan R, Ilagan O, Lawrence C, Levine S, Moar W, Mueller G, Tan J, Uffman J, Wiggins E, Heck G, Segers G (2012) Characterizing the mechanism of action of doublestranded RNA activity against western corn rootworm (Diabrotica virgifera virgifera LeConte). PLoS One 7:e47534

Carstens K, Cayabyab B, Schrijver A, Gadaleta GP, Hellmich RL, Romeis J, Storer N, Fernando H, Valicente FH, Wach W (2014) Surrogate species selection for assessing potential adverse environmental impacts of genetically engineered insect-resistant plants on nontarget organisms. GM Crops Food 5:11-15

CFIA (Canadian Food Inspection Service) (2012) Directive 94-08, revised July 4, 2012. Assessment criteria for determining environmental safety of plants with novel traits. CFIA, Ottawa. http://www.inspection.gc.ca/plants/ plants-with-novel-traits/applicants/directive-94-08/eng/130 4475469806/1304475550733. Accessed 29 Jan 2014

CFR (U.S. Code of Federal Regulations) (2008) Title 7, Part 340. Introduction of organisms and products altered or produced through genetic engineering which are plant pests or which there is reason to believe are plant pests. Animal and Plant Health Inspection Service, USDA

Comas J, Lumbierres B, Pons X, Albajes R (2013) Ex-Ante determination of the capacity of field tests to detect effects of genetically modified corn on non-target arthropods. J Econ Entomol 106(4):1659-1668

Comas C, Lumbierres B, Pons X, Albajes R (2014) No effects of Bacillus thuringiensis maize on nontarget organisms in the field in southern Europe: a meta-analysis of 26 arthropod taxa. Transgenic Res 23:135-143

Comas J, Lumbierres B, Pons X, Albajes R (2015) Optimizing the capacity of field trials to detect the effect of genetically 
modified maize on non-target organisms through longitudinal sampling. Ann Appl Biol 166:183-195

Devos Y, De Schrijver A, De Clercq P, Kiss J, Romeis J (2012) Bt-maize event MON 88017 expressing Cry3Bb1 does not cause harm to non-target organisms. Transgenic Res 21(6):1191-1214. doi:10.1007/s11248-012-96170z

Duan JJ, Marvier M, Huesing J, Dively G, Huang ZY (2008a) A meta-analysis of effects of Bt crops on honey bees (Hymenoptera: Apidae). PLoS One 3:e1415

Duan JJ, Teixeira D, Huesing JE, Jiang C (2008b) Assessing the risk to nontarget organisms from $\mathrm{Bt}$ corn resistant to corn rootworms (Coleoptera: Chrysomelidae): tier-I testing with Orius insidiosus (Heteroptera: Anthocoridae). Environ Entomol 37:838-844

Duan JJ, Lundgren JG, Naranjo S, Marvier M (2010) Extrapolating non-target risk of $\mathrm{Bt}$ crops from laboratory to field. Biol Lett 6:74-77

EFSA (European Food Safety Authority) (2004) Guidance document of the scientific panel on genetically modified organisms for the risk assessment of genetically modified plants and derived food and feed. EFSA J 99:1-94

Garcia-Alonso M, Jacobs E, Raybould A, Nickson TE, Sowing P, Willekens H, Van Der Kouwe P, Layton R, Amijee F, Fuentes AM, Teccalla F (2006) A tiered system for assessing the risk of genetically modified plants to non-target organisms. Environ. Biosaf Res 5:57-65. doi:10.1051/ebr:2006018

Garcia-Alonso M, Hendley P, Bigler F, Mayeregger E, Parker R, Rubinstein C, Satorre E, Solari F, McLean MA (2014) Transportability of confined field trial data for environmental risk assessment of genetically engineered plants: a conceptual framework. Transgenic Res 23:1025-1041

Horak MJ, Rosenbaum EW, Woodrum CL, Martens AB, Mery RF, Cothren JT, Burns JA, Nickson TE, Pester TA, Jiang C, Hart JE, Sammons B (2007) Characterization of flex roundup Ready cotton, 'MON88913', for use in ecological risk assessment: evaluation of seed germination, vegetative and reproductive growth, and ecological interactions. Crop Sci 47:268-277

Horak MJ, Rosenbaum EW, Kendrick DL, Sammons B, Phillips SL, Nickson TE, Dobert RC, Perez T (2015a) Plant characterization of Roundup Ready 2 Yield $^{\circledR}$ soybean, MON 89788 , for use in ecological risk assessment. Transgenic Res 24:213-225

Horak MJ, Rosenbaum EW, Phillips SL, Kendrick DL, Carson D, Clark PL, Nickson TE (2015b) Characterization of the ecological interactions of Roundup Ready 2 Yield $^{\circledR}$ soybean, MON 89788, for use in ecological risk assessment. Biotechnology in Agriculture and the Food Chain, GM Crops Food. doi:10.1080/21645698.2015.1067365

ILSI-CERA (2010) A review of the environmental safety of the CP4 EPSPS protein. International Life Sciences Institute, Center for Environmental Risk Assessment, Washington

ILSI-CERA (2014) A review of the environmental safety of the $\mathrm{Cry} 3 \mathrm{Bb} 1$ protein. International Life Sciences Institute, Center for Environmental Risk Assessment, Washington

Knecht S, Romeis J, Malone LA, Candolfi MP, Garcia-Alonso M, Habuštová O, Huesing JE, Kiss J, Nentwig W, Pons X, Rauschen S, Szénási Á, Bigler F (2010) A faunistic database as a tool for identification and selection of potential non-target arthropod species for regulatory risk assessment of GM maize. IOBC/WPRS Bulletin 52:65-69
Li Y, Meissle M, Romeis J (2008) Consumption of Bt maize pollen expressing Cry1 Ab or Cry3Bb1 does not harm adult green Lacewings, Chrysoperla carnea (Neuroptera: Chrysopidae). PLoS ONE 3:e2909

Li Y, Romeis J (2009) Bt maize expressing Cry3Bb1 does not harm the spider mite, tetranychus urticae, or its ladybird beetle predator, Stethorus punctillum. Biol Control 53:337-344. doi:10.1016/j.biocontrol.2009.12.003

Li Y, Meissle M, Romeis J (2010) Use of maize pollen by adult Chrysoperla carnea (Neuroptera: Chrysopidae) and fate of Cry proteins in Bt-transgenic varieties. J Insect Physiol 56:157-164

Li Y, Romeis J (2011) Laboratory toxicity studies demonstrate no adverse effects of Cry1Ab and Cry3Bb1 to larvae of Adalia bipunctata (Coleoptera: coccinellidae): the importance of study design. Transgenic Res 20(3):467-479. doi:10.1007/s11248-010-9430-5

Marvier M, McCreedy C, Regetz J, Kareiva P (2007) A metaanalysis of effects of Bt cotton and maize on nontarget invertebrates. Science 316:1475-1477

McManus BL, Fuller BW, Boetel MA, French BW, Ellsbury MM, Head GP (2005) Abundance of Coleomegilla maculata (Coleoptera: Coccinellidae) in corn rootworm-resistant Cry3Bb1 maize. J Econ Entomol 98:1992-1998

Meissle M, Álvarez-Alfageme F, Bigler F, Bohan DA, Devos Y, Malone LA, Pons X, Rauschen S, Romeis J (2013) Arthropods in European maize fields-describing the receiving environment for the risk assessment of GM crops. GMOs Integr Plant Prod 97:81-87

Nakai S, Hoshikawa K, Shimono A, Ohsawa R (2015) Transportability of confined field trial data from cultivation to import countries for the environmental risk assessment of genetically modified crops. Transgenic Res. doi:10.1007/ s11248-015-9892-6

Naranjo SE (2009) Impacts of Bt crops on non-target invertebrates and insecticide use patterns. CAB Rev: Perspect Agric Vet Sci Nut Nat Resour 4(011):1-23

Naranjo SE, Head G, Dively GP (2005) Field studies assessing arthropod nontarget effects in Bt transgenic crops: Introduction. Environ Entomol 34:1178-1180

Nickson TE (2008) Planning environmental risk assessment for genetically modified crops: problem formulation for stresstolerant crops. Plant Physiol 147:494-502

Palmer SJ, Krueger HO (1999) Bacillus thuringiensis protein 11231: a dietary toxicity study with green lacewing larvae (Chrysoperla carnea). Unpublished study commissioned by Monsanto Company (as reviewed in US EPA, 2002a)

Prasifka JR, Hellmich RL, Dively GP, Lewis LC (2005) Assessing the effects of pest management on nontarget arthropods: The influence of plot size and isolation. Environ Entomol 34:1181-1192

Prasifka JR, Hellmich RL, Dively GP, Higgins LS, Dixon PM, Duan JJ (2008) Selection of nontarget arthropod taxa for field research on transgenic insecticide crops: using empirical data and statistical power. Environ Entomol 37:1-10

Rauschen S, Schaarmschmidt F, Gathmann A (2010a) Occurrence and field densities of Coleoptera in the maize herb layer: implications for environmental risk assessment of genetically modified Bt-maize. Transgenic Res 19:727-744

Rauschen S, Schultheis E, Hunfeld H, Schaarschmidt F, Schuphan I, Eber S (2010b) Diabrotica-resistant Bt-maize 
DKC5143 event MON 88017 has no impact on the field densities of the leafhopper Zyginidia scutellaris. Environ Biosafety Res 9:87-99

Raybould A (2007) Ecological versus ecotoxicological methods for assessing the environmental risks of transgenic crops. Plant Sci 173:589-602

Raybould A (2010) Reducing uncertainty in regulatory decision-making for transgenic crops: more ecological research or clearer environmental risk assessment? GM Crops $1: 25-31$

Reyes SG (2005) Wet season population abundance of $M i$ craspis discolor (Fabr.) (Coleoptera: Coccinellidae) and Trichomma cnaphalocrosis Uchida (Hymenoptera: Ichnuemonidae) on three transgenic corn hybrids in two sites in the Philippines. Asian Life Sciences 14:217-224

Roberts A, Devos Y, Raybould A, Bigelow P, Gray A (2014) Environmental risk assessment of GE plants under low exposure conditions. Transgenic Res 23:971-983

Romeis J, Meissle M, Bigler F (2006) Transgenic crops expressing Bacillus thuringiensis toxins and biological control. Nat Biotechnol 24:63-71

Romeis J, Bartsch D, Bigler F, Candolfi MP, Gielkens MM, Hartley SE, Hellmich RL, Huesing JE, Jepson PC, Layton R, Quemada H, Raybould A, Rose RI, Schiemann J, Sears MK, Shelton AM, Sweet J, Vaituzis Z, Wolt JD (2008) Assessment of risk of insect-resistant transgenic crops to nontarget arthropods. Nat Biotechnol 26:203-208

Romeis J, Van Driesche RG, Barratt BIP, Bigler F (2009) Insect resistant transgenic crops and biological control. In: Romeis J, Shelton AM, Kennedy GG (eds) Integration of insect-resistant genetically modified crops within IPM programs. Springer, New York, pp 87-117

Romeis J, Hellmich RL, Candolfi MP, Carstens K, De Schrijver A, Gatehouse AMR, Herman R, Huesing JE, McLean MA, Raybould A, Shelton AM, Waggoner A (2011) Recommendations for the design of laboratory studies on nontarget arthropods for risk assessment of genetically engineered plants. Transgenic Res 20:1-22

Romeis J, Raybould A, Bigler F, Candolfi MP, Hellmich RL, Huesing JE, Shelton AM (2013) Deriving criteria to select arthropod species for laboratory tests to assess the ecological risks from cultivating arthropodresistant genetically engineered crops. Chemosphere 90:901-909

Rosca II (2004) Impact of genetically modified herbicide resistant maize on the arthropod fauna, GMOs in Integrated Production. IOBC wprs Bulletin 27:143-146
Rosca I, Cagan L (2012a) Research on the influence of genetically modified maize on the Coccinellidae fauna. IOBC/ wprs Bull 73:83-88

Rosca I, Cagan L (2012b) Research on the influence of genetically modified maize on the Neuroptera fauna. IOBC/wprs Bull 73:89-94

Rose RI (2006) Tier-based testing for effects of proteinaceous insecticidal plant-incorporated protectants on non-target arthropods in the context of regulatory risk assessments. IOBC WPR Bull. 29:145-152

SAS (2008) SAS/STAT software version 9.2. SAS Institute, Inc., Cary, North Carolina

SAS (2012) SAS/STAT software version 9.3. SAS Institute, Inc., Cary, North Carolina

Schier A (2006) Field study on the occurrence of ground beetles and spiders in genetically modified, herbicide tolerant corn in conventional and conservation tillage systems. J Plant Dis Protect 20:101-113

Sindermann AB, Porch JR, Krueger HO (2002) Evaluation of a Cry3Bb1 protein variant in a dietary toxicity study with parasitic Hymenoptera (Nasonia vitripennis). Unpublished study commissioned by Monsanto Company [as referred to in http://www.monsanto.com/products/Documents/safetys ummaries/yieldgard_rw_pss.pdf]

Svobodova Z, Habuštova O, Sehnal F, Holec M, Hussein HM (2012) Epigeic spiders are not affected by the genetically modified maize MON 88017. J Appl Entomol. doi:10. 1111/j.1439-0418.2012.01727.x

Svobodová Z, Habuštova O, Hussein HM, Puza V, Sehnal F (2012) Impact of genetically modified maize expressing Cry3Bb1 on non-target arthropods: first year results of a field study. IOBC/wprs Bull 73:107-120

U.S. EPA (2007) White paper on tier-based testing for the effects of proteinaceous insecticidal plant-incorporated protectants in non-target arthropods for regulatory risk assessments. U.S Environmental Protection Agency, Biotechnology Regulatory Services, Washington

Whyard S, Singh AD, Wong S (2009) Ingested double-stranded RNAs can act as species-specific insecticides. Insect Biochem Mol Biol 39:824-832

Wolfenbarger LL, Naranjo SE, Lundgren JG, Bitzer RJ, Watrud LS (2008) Bt crop effecs on functional guilds of non-target arthropods: a meta-analysis. PLoS One 3:e2118

Wolt J, Keese P, Raybould A, Fitzpatrick J, Burachik M, Gray A, Olin S, Schiemann J, Sears M, Wu F (2010) Problem formulation in the environmental risk assessment for genetically modified plants. Transgenic Res 19:425-436 